Встановлено закономірності адсорбційної поведінки полі$N, N^{\prime}$-діметілсафраніна та полі$\boldsymbol{N}, \boldsymbol{N}^{\prime}$-діетілсафраніна на міді. Показано, що ефективність впливу добавок на диференціальну ємність на межі розділу фаз електрод-електроліт залежить від рН середовища. Більша адсорбційна активність добавок проявляеться в кислому розчині, що може свідчити про більи сильну їх вирівнюючу дію при електроосадженні міді з кислого електроліту

Ключові слова: електроосадження, мідний електрод, адсорбиія, подвійний електричний шар, вирівнююча добавка

Установлены закономерности адсорбционного поведения поли-N, N'-диметилсафранина и поли-N, $N$ '-диэтилсафранина на меди. Показано, что әффективность влияния добавок на дифференциальную емкость на границе раздела фаз електродәлектролит зависит от рН среды. Большая адсорбционная активность добавок проявляется в кислом растворе, что может свидетельствовать о более сильном их выравнивающщем действии при электроосаждении меди из кислого электролита

Ключевые слова: электроосаждение, медный электрод, адсорбция, двойной электрический слой, выравнивающая добавка

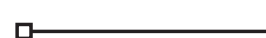

UDC 544.654.2

DOI: $10.15587 / 1729-4061.2017 .95724$

\section{INVESTIGATION OF ADSORPTION BEHAVIOR OF SMOOTHING ADDITIVES IN COPPER PLATING ELECTROLYTES}

I. Sk nar

$\mathrm{PhD}$, Associate Professor*

Department of Processes, Devices and General Chemical Technology* E-mail: juventa2011@gmail.com

L. Pe tre n k o

$\mathrm{PhD}$, Associate Professor Department of Chemistry and Chemical Technology of Macromolecular Compounds** E-mail: linapetrenko@gmail.com

A. Chere m y s in ova $\mathrm{PhD}$, Associate Professor Department of Processes, Apparatus and General Chemical Technology*

E-mail: Anna_Sokol_@i.ua

K. P I y a sov s k a y a

$\mathrm{PhD}$, Associate Professor Department of Physical and Inorganic Chemistry**

E-mail: pea1975@list.ru

Ya. Kozlov

$\mathrm{PhD}$, Associate Professor Department of Energetics* E-mail: and8705@yandex.ru

N. A mirulloyeva

$\mathrm{PhD}$, Associate Professor

Department of chemistry

Prydniprovs'ka State Academy of Civil Engineering and Architecture Chernyshevskoho str., 24a, Dnipro, Ukraine, 49600

E-mail: namirulloeva@ukr.net *Ukrainian State University of Chemical Technology Gagarina ave., 8, Dnipro, Ukraine, 49005

**Oles Honchar Dnipropetrovsk National University Gagarina ave., 72, Dnipro, Ukraine, 49010

\section{Introduction}

Adsorption of organic compounds is widely used to control the processes of metal electrodeposition. Surface-active substances can increase the electrolyte dissipation capacity, provide deposition of compact coatings with good adhesion to the substrate. Use of such compounds provides deposition of coatings with a high degree of gloss, low internal stresses and high hardness.

Depending on the nature of the metal and the required properties of the resulting coating, organic substances belonging to the most diverse classes of compounds are introduced into the precipitation electrolytes. The surfactants used should change the conditions of electrocrystallization of metals by adsorption on their surface. This method of modifying structure and morphology of the electroplated coating surface has found a wide application in obtaining electrolytic copper deposits. From the point of view of practical application in science-intensive industries, copper coatings belong to strategically important and demanded coatings in the present-day electronics and robotics.

The predictable effect on the structure and properties of electroplated copper coatings by introducing surfactants into electrolyte seems to be the most efficient and promising feature. Application of regulators of the copper deposit electrocrystallization requires a clear understanding of the is- 
sues related to the change in the state of the cathode surface in presence of these substances and their role in the copper electrodeposition mechanism.

The practical use of surfactants in the copper plating electrolytes has determined an intensive study of their effect on the properties of the coatings obtained. However, the issues related to the influence of surface-active substances on the kinetics and the mechanism of copper electrodeposition have been debatable until now. All of this hinders development of modern surfactant compositions ensuring directional control of the process of electrodeposition of copper coatings. The resulting deposits must have specified physico-chemical properties and performance characteristics.

Thus, identification of specific features of interaction of the surfactants used in electrodeposition of copper coatings with the copper electrode surface is a relevant task.

\section{Literature review and problem statement}

Electrochemical deposition of metals and alloys is the most flexible and controllable way of metal coating application. Kinetics and mechanism of metal electrodeposition largely depend on the composition of the depositing electrolytes [1]. Structure of electrochemical coatings is determined by the deposited metal nature and the electrolysis process conditions [2]. In turn, change in the deposit structure affects coating properties and applications [3].

Electrochemical deposition of copper coatings occupies one of the leading positions in the present-day electroplating practice. This process is widely used in production of printed circuit boards, automotive industry and electroforming. Lustrous copper coatings are used as sublayers for decorative nickel due to their higher elasticity and relative cheapness. Electrochemical method of copper deposition is used in the production of supercapacitors [4]. Nanotubes with electroplated copper coatings serve as anode collectors in lithium-ion batteries [5]. Copper is electrodeposited from simple and complex electrolytes at various $\mathrm{pH}$ values of such electrolytes [6].

To obtain smooth, shiny copper coatings, a complex of additives belonging to various classes of organic compounds is used [7]. As a rule, the organic additive compositions include suppressors, brighteners and equalizers.

Suppressors include polyethylene glycol, polypropylene glycol or their derivatives whose effect on the electrodeposition kinetics and structure of copper was investigated in [8]. In [9], tri-block copolymer with polyethylene glycol - polypropylene glycol - polyethylene glycol structure was proposed as a suppressor. Its adsorption behavior was studied by stripping voltammetry. Synergistic and antagonistic interaction between the suppressor and the anions chemisorbed on the surface of copper electrodes during electrodeposition was studied in [10].

Disulfides are used as brighteners: they increase strength, microhardness and glossiness of the electroplated copper coatings [11].

Leveling action on electrolytic copper deposits is exerted by surface-active sulfonates containing amine and amide groups [12]. Such organic compounds effectively inhibit reaction of electroreduction of copper ions and promote formation of uniform microcrystalline copper coatings. In particular, azine, phenazine, triphenylmethane dyes are used. Optimal concentration of Diazine Black (DB) dye was es- tablished in [13]: it provides the highest smoothing effect in electrodeposition of copper. In [14], nucleation of copper was studied for the electrochemical method of its deposition on a tungsten diffusion barrier in a neutral citrate electrolyte containing Janus Green B (JGB) dye. The authors of [15] investigated effect of this smoother on copper electrodeposition in an acidic sulfate electrolyte. Kinetics of formation and the structure of copper layers deposited from an acidic electrolyte for glossy copper plating containing a complex of organic additives were studied in [16]. Poly-N, N'-diethylsafranine dye was used as a smoothing additive.

Literature analysis shows that smoothing additives are required to obtain uniform and high-quality copper coatings. Dyes and their modifications act as such additives. At the same time, the literature data on adsorption and electrochemical properties of individual smoothing additives are rather scarce. This complicates choice of smoothing additives when working out compositions of the copper plating electrolytes. In this connection, it seems expedient to study surface activity of smoothing additives for the copper plating electrolytes, namely poly-N, N'-dimethylsafranine and poly-N, N'-diethylsafranine for electrolytes with acidic and neutral media.

\section{The objective and tasks of the study}

This paper's objective is to establish surface-behavior features of the smoothing additives for copper plating electrolytes representing organic polymer dyes and their effect on parameters of the electrode/solution interface. This will enable identification of optimal electrolysis conditions and acidity of copper plating electrolytes for the most efficient use of the dyes in question as smoothing additives.

To achieve this objective, the following tasks were solved:

- determine dependence of the differential capacitance of the double electrical layer of the copper electrode on the potential acting in sulfate electrolytes of different acidities in the presence of smoothing additives;

- determine adsorption and electrochemical activities of poly-N, N'-dimethylsafranine and poly-N, N'-diethylsafranine in sulfate electrolytes of different acidities.

\section{Materials and methods of research}

Differential capacitance of the double electrical layer of the copper electrode was measured by a bridge method.

Equilibrium values of differential capacitance can be only determined at sufficiently low frequencies of alternating current. When frequency increases, the measured capacitance decreases due to the fact that sinusoidal oscillations of the electrode potential cause corresponding changes in adsorption of various solution components when an alternating voltage is applied. In the case of low concentrations of adsorbed substances and a high frequency of alternating current, the adsorption equilibrium has no time to be established which leads to a decrease in the measured capacitance with growth of frequency.

The capacitive curves obtained in the presence of organic substances are characterized by the peaks, which correspond to the processes of adsorption-desorption of organic molecules. When these processes occur, the surface concentration and, correspondingly, electrode charge change sharply with 
the change of potential. This causes significant deviations in the capacitance values. At large electrode charges, the capacitive curves obtained in the presence of organic substances coincide with the background curve, which evidences desorption of organic molecules from the electrode surface [17].

A four-electrode cell and a research installation were used in the work. The installation consisted of an alternating current P-568 bridge, a frequency signal generator of GZ-56-1 type and a universal measuring device Sh-4313. The measuring instrument served to control amplitude of the alternating voltage applied to the electrode. The alternating voltage amplitude did not exceed $5 \mathrm{mV}$. Frequency of the alternating signal applied to the cell was $510 \mathrm{~Hz}$.

As an auxiliary electrode in the alternating current circuit, a platinum cylinder was used with the surface area exceeding the working electrode area by more than two orders of magnitude. A saturated calomel electrode (SCE) was used as the reference electrode.

A platinum wire in a separate vessel filled with a working solution was used as an auxiliary electrode in the DC circuit.

The working electrode was located in the center of the electrochemical cell. Its potential was set by an adjustable resistor.

The working electrode had a form of copper wire of the $\mathrm{MVCh}_{\mathrm{c}}$ type with a $99.993 \%$ base metal content pressed into a Teflon holder.

To degrease the electrode surface, treatment with Viennese lime was applied. Etching in concentrated nitric acid was carried out for $1-5$ seconds. Then, the electrode was electrochemically polished in a solution of phosphoric acid (density $\rho=1.55 \mathrm{~g} / \mathrm{cm}^{3}$ ) according to the following procedure. Orthophosphoric acid was heated to $65{ }^{\circ} \mathrm{C}$. Electropolishing was carried out for 70 seconds at a voltage of $1.0 \mathrm{~V}$ from a power source of B 5-47 type. After that, in order to dissolve possible oxide films formed during polishing, the electrode was held in $1 \mathrm{~N} \mathrm{H}_{2} \mathrm{SO}_{4}$ for 15 seconds. Interoperational washings of the electrode were carried out with distilled water.

The electrode was placed in the energized measuring cell containing $30 \mathrm{ml}$ of solution and cathodically polarized for 30-40 minutes at a potential of $-0.55 \mathrm{~V}$ (SCE). To remove dissolved oxygen, the solution under investigation was purged with argon for 90 minutes.

Capacitance was measured starting from the potential corresponding to the minimum current in the circuit in the direction of more negative potentials. The impedance spectrum was recorded in the region from 80 to $51,000 \mathrm{~Hz}$. The electrode surface did not change during measurements as evidenced by the reproducible values of capacitance and resistance when capacitive dependencies were plotted on the expiry of 20 minutes and one hour.

In view of high sensitivity of the method to the slightest traces of impurities, special attention was paid to purification of the reagents used. Sodium sulfate was recrystallized twice from the bidistillate and baked in a muffle furnace at a temperature of $500{ }^{\circ} \mathrm{C}$ for 4 hours. To absorb traces of oxygen contained in the argon used in this work, the latter was passed through a solution of pyrogallol, concentrated sulfuric acid and three traps with bidistilled water.

The cell and all utensils used in the work were previously washed with a mixture of concentrated sulfuric acid and hydrogen peroxide in a ratio of 3:1. After that, they were thoroughly washed with small portions of di- and tridistilled water.
Poly-N, N'-dimethylsafranine and poly-N, N'-diethylsafranine were used as smoothing agents.

Electrochemical studies were carried out with plotting cathodic voltammograms with the copper electrode in sulfate solutions with a variable concentration of smoothing additives. Polarization dependencies were obtained using a serial instrument cluster:

1) PI-50-1 potentiostat;

2) PR-8 programmer;

3) two-coordinate LKD-4-003 recorder;

4) glass three-electrode electrolytic cell.

\section{The results obtained in the study of adsorption of smoothing additives on the copper electrode in acidic and neutral solutions}

Poly-N, N'-dimethylsafranine and poly-N, N'-diethylsafranine additives are polymeric compounds containing quaternary ammonium cations and amino groups. Since the state of these substances depends on the solution $\mathrm{pH}$, the adsorption behavior of the two additives was studied in acidic ( $\mathrm{pH}$ 1.7) and neutral (pH 5.9) media. Capacitive dependencies obtained from the solutions in the presence of poly-N, N'-dimethylsafranine and poly-N, N'-diethylsafranine were equilibrium. Adsorption equilibrium in both acidic and neutral solutions was established rapidly and varied slightly with time.

The established dependence of the differential capacitance of the double electric layer of the copper electrode on the potential in $0.25 \mathrm{M} \mathrm{Na}_{2} \mathrm{SO}_{4}$ solution at $\mathrm{pH} 1.7$ was characterized by the presence of maximum at the electrode potential of $-0.50 \mathrm{~V}$ (Fig. 1, 2). Appearance of this maximum is connected with desorption of $\mathrm{HSO}_{4}^{-}$anions from the copper electrode surface [18]. Preferential adsorption of $\mathrm{HSO}_{4}^{-}$ anions with respect to sulfate anions in sulfate electrolytes is explained by the lower energy of hydration of these particles which are squeezed onto the interphase boundary.

When introducing additives into the background electrolyte, the capacitive dependence retains its form but passes through lower capacitance values compared to the background curve. Besides, an increase in the content of organic additives in electrolyte promotes reduction of the peak height in the differential capacitance dependence on the potential. Obviously, this behavior of the copper electrode in the sulfate electrolyte is caused by adsorption of additives on the electrode surface.

The organic compounds of poly-N, N'-dimethylsafranine and poly-N, N'-diethylsafranine with their rather large sizes promote increase in the distance between the capacitor plates in the double layer and, consequently, decrease in its capacity. The maximum value of the additive adsorption corresponds to the cathodic minimum of the dependence of the differential capacitance of the double electrical layer of the copper electrode on the potential, since it is much deeper than the anodic minimum. The differential capacity minimum in the presence of poly-N, N'-dimethylsafranine and poly-N, N'-diethylsafranine due to the maximum adsorption of additives corresponds to a potential of $-0.65 \mathrm{~V}$.

Increase in concentration of poly-N, N'-dimethylsafranine and poly-N, N'-diethylsafranine results in some shift of the minimum of the differential capacitance of the double electrical layer of the copper electrode corresponding to the maximum adsorption of additives to the region of more 
negative potentials. This means that the positively charged amine groups which are in a protonated state in an acidic medium participate in the adsorption interaction with the cathode surface.

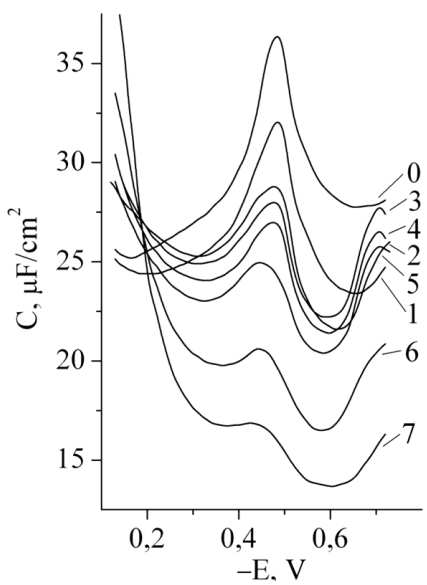

Fig. 1. Dependence of differential capacitance (C) of the copper electrode on potential (E) in $0.25 \mathrm{M} \mathrm{Na}_{2} \mathrm{SO}_{4}$ solution at $\mathrm{pH} 1.7$ with concentration of poly-N, N'-dimethylsafranine,

g/l: $0-0 ; 1-10^{-5} ; 2-5 \cdot 10^{-5} ; 3-10^{-4} ; 4-5 \cdot 10^{-4}$; $5-10^{-3} ; 6-5 \cdot 10^{-3} ; 7-10^{-2}$

At the same time, when the potential of the copper electrode is shifted to the negative side after the deep minimum observed in the potential range $-0.6 \div-0.7 \mathrm{~V}$, the differential capacitance increases. However, the cathodic peak on the capacitive curve specific for the quaternary ammonium cation does not reveal itself in this case. Probably, such cations can form peculiar ionic pairs with sulfate anions and chloride anions. The adsorption behavior of the formed associates corresponds to the neutral surface-active molecules.

In solutions with poly-N, N'-dimethylsafranine, a sharp increase in capacitance is observed in the region of potentials close to the zero-charge potential. This may be due to the desorption of the additive with a lower molecular weight from the electrode surface. In the presence of poly-N, N'-diethylsafranine, this effect is only typical of the solutions with small additive contents $\left(10^{-5}-10^{-4} \mathrm{~g} / \mathrm{l}\right)$.

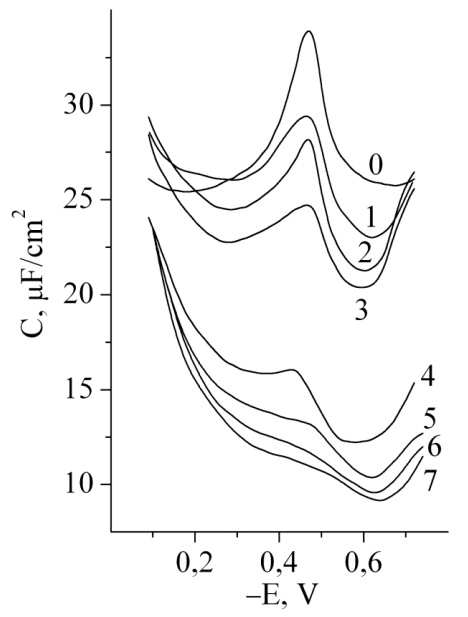

Fig. 2. Dependence of differential capacitance (C) of the copper electrode on potential (E) in $0.25 \mathrm{M} \mathrm{Na}_{2} \mathrm{SO}_{4}$ solution at $\mathrm{pH} 1.7$ with concentration of poly-N, N'- diethylsafranine, g/l: $0-0 ; 1-10^{-5} ; 2-5 \cdot 10^{-5} ; 3-10^{-4} ; 4-5 \cdot 10^{-4}$; $5-10^{-3} ; 6-5 \cdot 10^{-3} ; 7-10^{-2}$
The form of the dependence of the differential capacitance of the double electric layer of the copper electrode on the potential obtained in a neutral solution of sodium sulfate differs markedly from that in the case of acidic solution. Content of $\mathrm{SO}_{4}^{2-}$ ions in a neutral solution is much higher than the content of $\mathrm{HSO}_{4}^{-}$. ions. Therefore, the flat maximum observed in the background curve of the dependence of the differential capacitance on the potential of the electrode at a potential value of $-0.65 \mathrm{~V}$ should be attributed to desorption of sulfate anions (Fig. 3, 4).

When organic additives of poly-N, N'-dimethylsafranine and poly-N, N'-diethylsafranine are added to the electrolyte in a quantity of $10^{-4} \mathrm{~g} / \mathrm{l}$, the dependence of the differential capacitance of the double electrical layer of the copper electrode repeats the shape of the background curve. The potential of maximum does not change and its height is somewhat reduced.

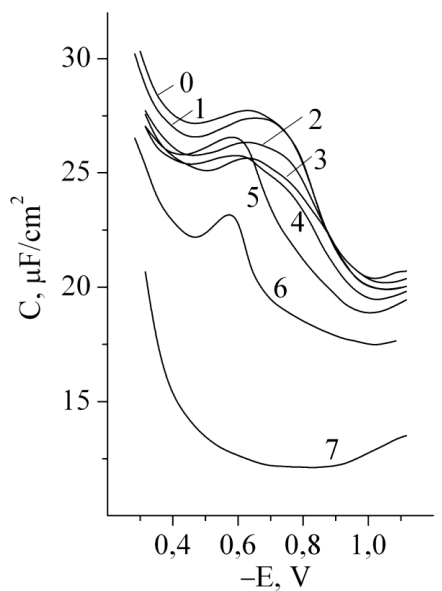

Fig. 3. Dependence of differential capacitance (C) of the copper electrode on potential (E) in $0.25 \mathrm{M} \mathrm{Na}_{2} \mathrm{SO}_{4}$ solution at $\mathrm{pH} 5.9$ with concentration of poly-N, $\mathrm{N}^{\prime}$ - dimethylsafranine, g/I: $0-0 ; 1-10^{-5} ; 2-5 \cdot 10^{-5} ; 3-10^{-4} ; 4-5 \cdot 10^{-4}$; $5-10^{-3} ; 6-5 \cdot 10^{-3} ; 7-10^{-2}$

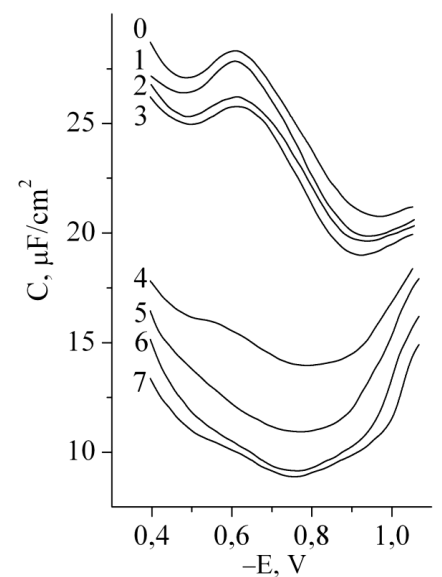

Fig. 4. Dependence of differential capacitance (C) of the copper electrode on potential (E) in $0.25 \mathrm{M} \mathrm{Na}_{2} \mathrm{SO}_{4}$ solution at $\mathrm{pH} 5.9$ with concentration of poly-N, N'- diethylsafranine,

$\mathrm{g} / \mathrm{l}: 0-0 ; 1-10^{-5} ; 2-5 \cdot 10^{-5} ; 3-10^{-4} ; 4-5 \cdot 10^{-4}$; $5-10^{-3} ; 6-5 \cdot 10^{-3} ; 7-10^{-2}$

Increase in concentration of organic substances results in a change in the shape of the capacitive dependence. It 
acquires a form characteristic of the case of adsorption of a molecular-type additive. In solutions with the addition of poly-N, N'-dimethylsafranine, this occurs at a concentration of $10^{-2} \mathrm{~g} / \mathrm{l}$, and at $5 \cdot 10^{-4} \mathrm{~g} / \mathrm{l}$ for poly-N, N'-diethylsafranine. Obviously, the amine group is not protonated in a neutral solution and, unlike acidic solutions, its interaction with the cathode surface is not realized. It is characteristic that no shift of minimum of the capacitive curve to the negative potential region is observed in neutral electrolytes when concentration of poly-N, N'-dimethylsafranine increases.

As can be seen from Fig. 4, two cathodic minima are observed in solutions containing poly-N, N'-diethylsafranine: one in the range of additive concentration $10^{-5}-10^{-4} \mathrm{~g} / \mathrm{l}$ and the other in solutions with higher concentrations of the additive $\left(5.10^{-4}-10^{-2} \mathrm{~g} / \mathrm{l}\right)$. The values of the potentials corresponding to these minima of the capacitive curves do not change in these ranges of the additive concentrations.

Like for the case of acidic solution, the maximum additive adsorption in neutral solutions corresponds to the cathode minimum of dependence of the differential capacitance of the double electric layer of the copper electrode on the potential, since it is much deeper than the anode minimum.

Along with the dependences of the differential capacitance of the double electric layer of the copper electrode in the electrolytes under study, current-voltage curves of hydrogen evolution were plotted (Fig. 5, 6).

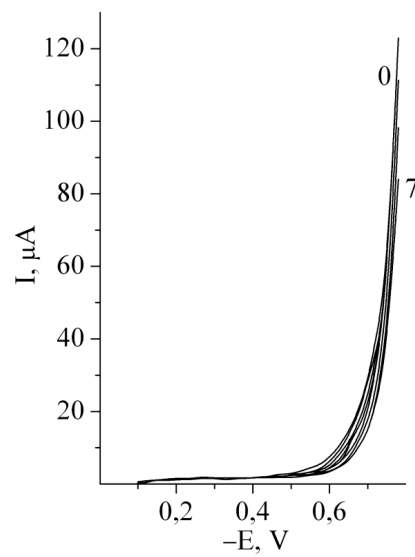

a

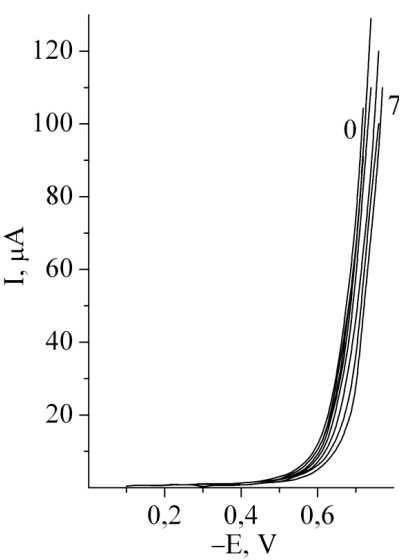

$b$
Fig. 5. Current-voltage dependencies of hydrogen evolution on the copper electrode in $0.25 \mathrm{M} \mathrm{Na}_{2} \mathrm{SO}_{4}$ solution at $\mathrm{pH} 1.7$ in the presence of additives: $a$ - poly-N, N'-dimethylsafranin; $b$ - poly-N, N'-diethylsafranin. Additive concentrations, $\mathrm{g} / \mathrm{I}$ : $0-0 ; 1-10^{-5} ; 2-5 \cdot 10^{-5} ; 3-10^{-4} ; 4-5 \cdot 10^{-4} ; 5-10^{-3}$; $6-5 \cdot 10^{-2} ; 7-10^{-2}$

As can be seen from Fig. 5, an increase in concentration of poly-N, N'-dimethylsafranine and poly-N, N'-diethylsafranine results in a growth of overvoltage of hydrogen evolution. The exception is neutral solutions with a high content of additives, the concentration of which exceeds $5.10^{-3} \mathrm{~g} / \mathrm{l}$ (Fig. 6). In these electrolytes, there is an increase in current in the region of more positive potentials compared to the solutions with lower additive concentrations. One of the possible reasons for this effect can be occurrence of the Faraday process of additive electroreduction. In this case, the frequency dependence of the differential capacitance of the double electrical layer of the copper electrode should be observed. However, as can be seen from the data in Table 1, the capacitance values vary little with frequency at potentials $\mathrm{E}=-0.6 \mathrm{~V}$ and $\mathrm{E}=-0.85 \mathrm{~V}$.
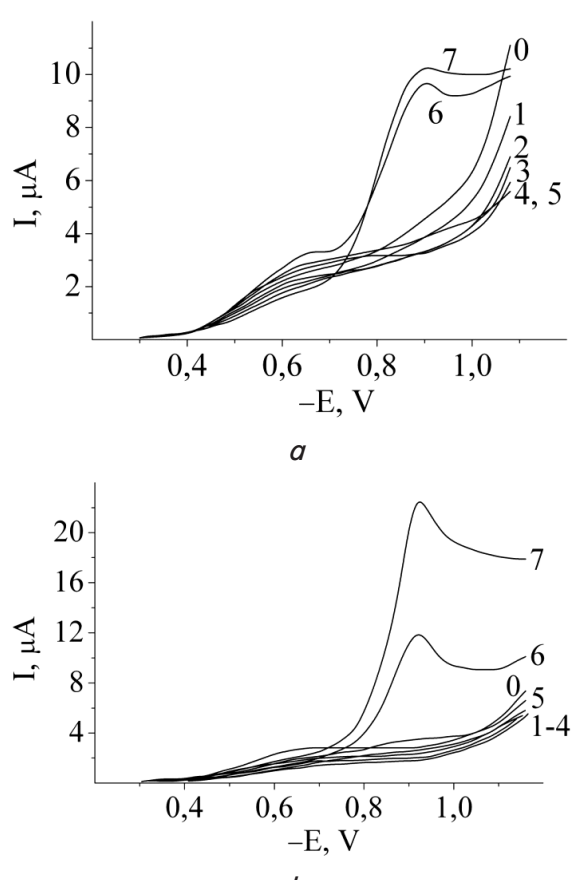

b

Fig. 6. Current-voltage dependences of hydrogen evolution on the copper electrode in $0.25 \mathrm{M} \mathrm{Na}_{2} \mathrm{SO}_{4}$ solution at $\mathrm{pH} 5.9$ in the presence of additives: $a-$ poly-N, N'-dimethylsafranin; $b-$ poly-N, N'-diethylsafranin. Additive concentrations, g/l: $0-0 ; 1-10^{-5} ; 2-5 \cdot 10^{-5} ; 3-10^{-4} ; 4-5 \cdot 10^{-4} ; 5-10^{-3}$; $6-5 \cdot 10^{-2} ; 7-10^{-2}$

Table 1

Frequency dependence of the differential capacitance of the double electrical layer of the copper electrode with an area $S=0.14777 \mathrm{~cm}^{2}$ in a background electrolyte and in the presence of an additive

\begin{tabular}{|c|c|c|c|}
\hline \multirow{5}{*}{ E, V } & $v, \mathrm{~Hz}$ & $\begin{array}{c}0.25 \mathrm{M} \mathrm{Na}_{2} \mathrm{SO}_{4}, \mathrm{C}, \\
\mu \mathrm{F} / \mathrm{cm}^{2}\end{array}$ & $\begin{array}{c}0,25 \mathrm{M} \mathrm{Na}_{2} \mathrm{SO}_{4}+ \\
+10^{-2} \mathrm{~g} / \mathrm{ladditive}, \\
\mathrm{C}, \mu \mathrm{F} / \mathrm{cm}^{2}\end{array}$ \\
\hline \multirow{5}{*}{0.6} & 510 & 3.45 & 2.50 \\
\cline { 2 - 4 } & 810 & 3.25 & 2.40 \\
\cline { 2 - 4 } & 11,000 & 2.60 & 2.10 \\
\cline { 2 - 4 } & 21,000 & 2.50 & 2.10 \\
\cline { 2 - 4 } & 31,000 & 2.70 & 2.20 \\
\cline { 2 - 4 } & 36,000 & 2.70 & 2.60 \\
\cline { 2 - 4 } & 41,000 & 3.20 & 2.70 \\
\cline { 2 - 4 } & 51,000 & 3.20 & 2.70 \\
\hline \multirow{5}{*}{0.85} & 510 & 3.50 & 2.25 \\
\cline { 2 - 5 } & 810 & 3.30 & 2.15 \\
\cline { 2 - 4 } & 11,000 & 2.70 & 1.80 \\
\cline { 2 - 4 } & 21,000 & 2.60 & 2.00 \\
\cline { 2 - 4 } & 31,000 & 2.60 & 2.00 \\
\cline { 2 - 4 } & 36,000 & 3.10 & 2.00 \\
\cline { 2 - 4 } & 41,000 & 3.10 & 2.20 \\
\cline { 2 - 4 } & 51,000 & 3.10 & 2.50 \\
\hline
\end{tabular}

Consequently, increase in current at low values of the cathodic potential found for the solutions concentrated in additives at pH 5.9 (Fig. 6) is not related to the electroreduction of organic additives. Probably, electroreduction of surface oxides formed on the copper surface in a neutral medium takes place there. 


\section{Discussion of the results obtained in examining the adsorption activity of the smoothing additives on the copper electrode in acidic and neutral sulfate solutions}

When copper is electrodeposited in the presence of smoothing additives, the surface microprofile is smoothed as a result of the current density redistribution towards its increase in the profile valleys. This effect is determined by the different degrees of inhibition of peaks and valleys by organic compounds due to the fact that the diffusional accessibility of the peaks for the adsorbing additive is higher. Thus, the more accessible (in respect of diffusion) cathode sites grow more slowly. The inhibitory effect of the additive is determined by its adsorption properties.

To evaluate the adsorption activity of poly-N, N'-dimethylsafranine and poly-N, N'-diethylsafranine, it is advisable to use the value of relative decrease in the differential capacitance $(\Delta C)$ of the double electrical layer of the copper electrode when introducing additives to the electrolyte at a specified potential calculated based on the data given in Fig. 1-4. The corresponding results are given in Tables 2, 3 .

Table 2

Dependence of the relative decrease in capacitance of the double electrical layer of the copper electrode on the concentration of poly- $\mathrm{N}, \mathrm{N}^{\prime}$-dimethylsafranine

\begin{tabular}{|c|c|c|}
\hline $\begin{array}{c}\text { Concentration of } \\
\text { polyN, N'-dimethyl- } \\
\text { safranine, g/l }\end{array}$ & $\mathrm{pH} 1.7\left(\mathrm{E}_{\min }=-0.65\right)$ & $\mathrm{pH} 5.9\left(\mathrm{E}_{\min }=-1.0\right)$ \\
\hline $10^{-5}$ & $4 \mathrm{C}, \mu \mathrm{F} / \mathrm{cm}^{2}$ & $\Delta \mathrm{C}, \mu \mathrm{F} / \mathrm{cm}^{2}$ \\
\hline $5 \cdot 10^{-5}$ & 5.95 & 0.30 \\
\hline $10^{-4}$ & 6.70 & 0.55 \\
\hline $5 \cdot 10^{-4}$ & 6.70 & 0.55 \\
\hline $10^{-3}$ & 7.50 & 1.10 \\
\hline $5 \cdot 10^{-3}$ & 11.30 & 1.70 \\
\hline $10^{-2}$ & 14.60 & 3.10 \\
\hline & & 8.70 \\
\hline
\end{tabular}

Table 3

Dependence of the relative decrease in capacitance of the double electrical layer of the copper electrode on the concentration of poly-N, N'-diethylsafranine

\begin{tabular}{|c|c|c|}
\hline $\begin{array}{c}\text { Concentration of } \\
\text { polyN, N'-diethylsa- } \\
\text { franine, g/ } 1\end{array}$ & $\mathrm{pH} 1.7\left(\mathrm{E}_{\min }=-0.65\right)$ & $\mathrm{pH} 5.9\left(\mathrm{E}_{\min }=-1.0\right)$ \\
\cline { 2 - 3 } & $\Delta \mathrm{C}, \mu \mathrm{F} / \mathrm{cm}^{2}$ & $\Delta \mathrm{C}, \mu \mathrm{F} / \mathrm{cm}^{2}$ \\
\hline $10^{-5}$ & 3.05 & 1.00 \\
\hline $5 \cdot 10^{-5}$ & 4.75 & 1.30 \\
\hline $10^{-4}$ & 5.65 & 1.95 \\
\hline $5 \cdot 10^{-4}$ & 13.85 & 7.65 \\
\hline $10^{-3}$ & 16.15 & 11.20 \\
\hline $5 \cdot 10^{-3}$ & 17.05 & 13.15 \\
\hline $10^{-2}$ & 17.50 & 13.35 \\
\hline
\end{tabular}

As it follows from the analysis of the data presented in Tables 2, 3, effectiveness of influence of the studied additives on the capacity of the double electrical layer of the copper electrode is determined by the additive nature and the medium acidity. Higher adsorption activities of the studied organic substances are observed in acidic solutions.

The probable cause of increased additive adsorbability in solutions with low $\mathrm{pH}$ values is the transition of these organic compounds to the protonated state in an acid medium with the formation of positively charged amino groups. Cationic groups of the additive are responsible for an additional interaction with the cathode surface. They provide a stronger adsorption of poly-N, N'-dimethylsafranine and poly-N, N'-diethylsafranine on the copper electrode in comparison with neutral electrolytes. Sulfate ions and chloride ions which specifically adsorb on copper can facilitate entry of positively charged groups of organic compounds into the double electric layer. This effect is due to the formation of a bridge between the copper surface and organic compounds [19]. It is noteworthy that poly-N, N'-diethylsafranine having larger molecular weight in comparison with poly-N, N'-dimethylsafranine has greater adsorbability.

Since the smoothing effect of additives is determined by their adsorption properties, it should be expected that electrodeposition of copper coatings will be most effectively with the use of poly-N, N'-diethylsafranine. The $\mathrm{pH}$ values of copper plating electrolytes must be decreased in so doing.

\section{Conclusions}

1. The adsorption behavior of such smoothing additives to copper plating electrolytes as poly-N, N'-dimethylsafranine and poly-N, N'-diethylsafranine which are compounds containing quaternary cations and amino groups was studied for the copper electrodes. Adsorption of additives was studied by measuring differential capacitance of the double electric layer. It has been established that the capacitive dependences obtained in the presence of poly-N, N'-dimethylsafranine and poly-N, N'-diethylsafranine in acidic electrolytes with pH 1.7 are characterized by two minima corresponding to the maximum adsorption of additives at $-0.35 \mathrm{~V}$ (SCE) and $-0.65 \mathrm{~V}$ (SCE). More pronounced is the minimum observed at a potential of $-0.65 \mathrm{~V}$ (SCE). In the neutral sulfate solutions with a pH 5.9, this minimum is shifted to the region of more negative potentials.

2. It was shown that the studied additives manifested their higher adsorption activity in acidic solutions. The stronger interaction of the additives with the copper surface is explained by the fact that their amine groups are in the protonated state and are positively charged. This helps reduce the difficulty of the organic compound entry into the double electrical layer. A transition bridge is formed between the copper surface and the organic compounds due to their interaction with copper sulfate ions and chloride ions specifically adsorbed on copper. It was established that the relative decrease in the differential capacitance of the double electric layer of the copper electrode, both in acidic and neutral solutions containing poly-N, N'-diethylsafranine, exceeds that for poly-N, N'-dimethylsafranine. This regularity is due to the difference in the molecular weight of the studied substances the value of which is greater in the case of poly-N, $\mathrm{N}$-dimethylsafranin. This obviously leads to a greater adsorption of poly-N, N'-diethylsafranine in comparison with poly-N, N'-dimethylsafranine on a copper electrode. The data obtained by plotting cathodic voltammograms in electrolytes containing smoothing additives have shown that these compounds do not possess electrochemical activity in the investigated potential region. It was established that the acid electrolyte is preferred for the use with the studied smoothing additives. 


\section{Acknowledgments}

The authors are deeply grateful to Mrs. Alla Kuprik, Candidate of Chemical Sciences, Associate Professor of the Physical Chemistry and Electrochemistry Department of O. Gonchar National University, Dnipro, Ukraine, for the fruitful participation in discussion of the obtained results.

\section{References}

1. Danilov, F. I. Kinetics of nickel electroplating from methanesulfonate electrolyte [Text] / F. I. Danilov, I. V. Sknar, Yu. E. Sknar // Russian Journal of Electrochemistry. - 2011. - Vol. 47, Issue 9. - P. 1035-1042. doi: 10.1134/s1023193511090114

2. Sknar, Yu. E. Influence of Methylsulfonate Anions on the Structure of Electrolytic Cobalt Coatings [Text] / Yu. E. Sknar, N. V. Amirulloeva, I. V. Sknar, F. I. Danylov // Materials Science. - 2016. - Vol. 52, Issue 3. - P. 396-401. doi: 10.1007/s11003016-9970-9

3. Danilov, F. I. Structure and properties of Ni-Co alloys electrodeposited from methanesulfonate electrolytes [Text] / F. I. Danilov, V. N. Samofalov, I. V. Sknar, Yu. E. Sknar, A. S. Baskevich, I. G. Tkach // Protection of Metals and Physical Chemistry of Surfaces. - 2015. - Vol. 51, Issue 5. - P. 812-816. doi: 10.1134/s2070205115050068

4. Eugenio, S. Electrodeposition and characterization of nickel-copper metallic foams for application as electrodes for supercapacitors [Text] / S. Eugenio, T. M. Silva, M. J. Carmezim, R. G. Duarte, M. F. Montemor // Journal of Applied Electrochemistry. - 2013. Vol. 44, Issue 4. - P. 455-465. doi: 10.1007/s10800-013-0646-y

5. Yehezkela, S. Distinct Copper Electrodeposited Carbon Nanotubes (CNT) Tissues as Anode Current Collectors in Li-ion Battery [Text] / S. Yehezkel, M. Auinat, N. Sezin, D. Starosvetsky, Y. Ein-Eli // Electrochimica Acta. - 2017. - Vol. 229. - P. 404-414. doi: 10.1016/j.electacta.2017.01.175

6. Lizama-Tzec, F. I. Electrodeposition of copper into trenches from a citrate plating bath [Text] / F. I. Lizama-Tzec, L. Canche-Canul, G. Oskam // Electrochimica Acta. - 2011. - Vol. 56, Issue 25. - P. 9391-9396. doi: 10.1016/j.electacta.2011.08.023

7. Modern Electroplating [Text] / M. Schlesinger, M. Paunovic (Eds.). - New York: John Wiley \& Sons, Inc, $2010 .-729$ p. doi: 10.1002/9780470602638

8. Wafula, F. Impact of Key Deposition Parameters on the Voiding Sporadically Occurring in Solder Joints with Electroplated Copper [Text] / F. Wafula, Y. Liu, L. Yin, S. Bliznakov, P. Borgesen, E. J. Cotts, N. Dimitrov // Journal of The Electrochemical Society. 2010. - Vol. 157, Issue 2. - P. D111. doi: 10.1149/1.3271129

9. Xiao, N. Adsorption behavior of triblock copolymer suppressors during the copper electrodeposition [Text] / N. Xiao, D. Li, G. Cui, N. Li, Q. Li, G. Wu // Electrochimica Acta. - 2014. - Vol. 116. - P. 284-291. doi: 10.1016/j.electacta.2013.11.056

10. Broekmann, P. Classification of suppressor additives based on synergistic and antagonistic ensemble effects [Text] / P. Broekmann, A. Fluegel, C. Emnet, M. Arnold, C. Roeger-Goepfert, A. Wagner et. al. // Electrochimica Acta. - 2011. - Vol. 56, Issue 13. P. 4724-4734. doi: 10.1016/j.electacta.2011.03.015

11. Chrzanowska, A. Effect of interaction between dodecyltrimethylammonium chloride (DTAC) and bis(3-sulphopropyl) disulphide (SPS) on the morphology of electrodeposited copper [Text] / A. Chrzanowska, R. Mroczka, M. Florek // Electrochimica Acta. 2013. - Vol. 106. - P. 49-62. doi: 10.1016/j.electacta.2013.05.061

12. Takeuchi, M. Single Diallylamine-Type Copolymer Additive Which Perfectly Bottom-Up Fills Cu Electrodeposition [Text] / M. Takeuchi, K. Kondo, H. Kuri, M. Bunya, N. Okamoto, T. Saito Journal of The Electrochemical Society. - 2012. - Vol. 159, Issue 4. - P. D230. doi: 10.1149/2.080204jes

13. Dow, W.-P. Microvia filling by copper electroplating using diazine black as a leveler [Text] / W.-P. Dow, C.-C. Li, Y.-C. Su, S.-P. Shen, C.-C. Huang, C. Lee et. al. // Electrochimica Acta. - 2009. - Vol. 54, Issue 24. - P. 5894-5901. doi: 10.1016/j.electacta.2009.05.053

14. Im, B. Effect of bath additives on copper electrodeposited directly on diffusion barrier for integrated silicon devices [Text] / B. Im, S. Kim // Thin Solid Films. - 2013. - Vol. 546. - P. 263-270. doi: 10.1016/j.tsf.2013.03.075

15. Dow, W.-P. Influence of Convection-Dependent Adsorption of Additives on Microvia Filling by Copper Electroplating [Text] / W.-P. Dow, H.-S. Huang, M.-Y. Yen, H.-C. Huang // Journal of The Electrochemical Society. - 2005. - Vol. 152, Issue 6. - P. C425. doi: $10.1149 / 1.1901670$

16. Rashkov, R. Effect of surface active agents on the initial formation of electrodeposited copper layers [Text] / R. Rashkov, C. Nanev // Journal of Applied Electrochemistry. - 1995. - Vol. 25, Issue 6. - P. 603-608. doi: 10.1007/bf00573218

17. Damaskin, B. B. Electrochemistry [Text]: ucheb. / B. B. Damaskin, O. A. Petrij, G. A. Cirlina. - 2-e izd., ispr. i pererab. - Moscow: Chemistry, KolosS, 2006. - 672 p.

18. Kuprik, A. V. Nature of the maximum on the curves of differential capacity in copper sulfate solutions [Text] / A. V. Kuprik, V. V. Trofimenko, M. N. Ben-Lee, Y. M. Loshkarev // Ukrainian Chemical Journal. - 1984. - Vol. 50, Issue 5. - P. 506-508.

19. Damaskin, B. B. Coadsorption of organic cations with different anions at the interface solution/mercury and the solution/air [Text] / B. B. Damaskin, V. M. Gerovich, M. I. Podgornaya // Electrochemistry. - 1986. - Vol. 22, Issue 1. - P. 114-119. 